\title{
PENGgunAan EXTREME PROGRAMMING UNTUK RANCANG BANGUN APLIKASI SEKRETARIAT PAROKI (STUdi Kasus PADA GEREJA KaTOLIK SANTO PETRUS PALEMBANG)
}

\author{
Stefanus Setyo Wibagso, Sistem Informasi, FST Unika Musi Charitas Palembang
}

\begin{abstract}
Abstrak - Sebagai bagian dari organisasi Gereja Katolik, sekretariat Paroki mempunyai peran penting didalam mendata informasi yang berkaitan dengan umat Paroki karena pekerjaannya sangat membantu dan mendukung tugas Pastor Paroki didalam mengelola administrasi Gereja. Dalam pelaksanaannya di Gereja Katolik Paroki Santo Petrus Palembang, petugas sekretariat menghadapi beberapa permasalahan dikarenakan aplikasi yang digunakan hanya mampu mengolah satu kegiatan saja yaitu mendokumentasikan data Sakramen Baptis. Sementara untuk pengolahan data lainnya masih dilakukan secara manual. Tujuan dari penelitian ini adalah untuk membangun sebuah aplikasi yang melengkapi kekurangan dari aplikasi yang telah ada. Untuk menghasilkan aplikasi yang dapat berjalan dengan baik dan sesuai dengan kebutuhan maka dibutuhkan metode didalam proses perancangannya. Metode Extreme Programming menjadi pilihan dalam perancangan ini dikarenakan cocok untuk digunakan dalam perancangan aplikasi berskala kecil.
\end{abstract}

Kata Kunci-Aplikasi Sekretariat Paroki, Gereja Katolik, Extreme Programming

Abstract-As part of the Catholic Church organization, the Parish Secretariat has an important role in recording information relating to parishioners. The work of the Parish Secretariat staff is very helpful in supporting the Parish Priest's task in managing the administration of the Church. In its implementation in the Parish Catholic Church of St. Peter Palembang, the secretariat staff faced several problems because the application was only able to process one activity, namely documenting Baptist data. While other data processing is still done manually. The purpose of this study is to build applications that complement the shortcomings of existing applications. To produce applications that can run well and in accordance with needs, the method in the design process is needed. Extreme Programming method is the choice in this design because it is suitable for use in designing small scale applications.
Index Term-Parish Secretariat Application, Catholic Church, Extreme Programming

\section{PENDAHULUAN}

G ereja merupakan tempat dimana diselenggarakan ibadah atau upacara keagamaan bagi umat Kristen. Selain dari itu Gereja merupakan sebuah badan / organisasi non profit yang melakukan pelayanan terhadap jemaatnya [5]. Salah satu hirarki dari organisasi Gereja Katolik adalah Paroki. Secara teoritis dikatakan bahwa paroki adalah komunitas kaum beriman yang dibentuk secara tetap dengan batas-batas kewilayahan tertentu dalam keuskupan [8]. Di dalam Gereja Katolik terdapat banyak pelayanan rohani yang diberikan kepada jemaat di Paroki melalui Pastor Paroki selain memimpin ibadah di hari Minggu. Beberapa diantaranya adalah melakukan sakramen baptis, sakramen krisma, sakramen perkawinan, memimpin ibadah kematian, memimpin ibadah pemberkatan rumah, dan lain-lain yang menyangkut pendampingan rohani ke jemaat. Ativitas kegiatan pelayanan yang diberikan oleh Pastor Paroki di catat dan disimpan oleh Sekretariat Paroki dengan cara sebagian manual dan sebagian menggunakan aplikasi komputer. Hal ini dipandang tidak efektif dan tidak efisien jika dilihat dari cara penyimpanan data yang masih terpisah. Jika melihat dari pertumbuhan jumlah umat yang terus berubah dari tahun ke tahun bahkan dalam hitungan minggu maka dapat diperkirakan data-data tersebut akan semakin membesar sehingga lebih sulit untuk dirapikan.

Konsep penyimpanan data dengan menggunakan teknologi basis data komputer dan dikombinasikan dengan program aplikasi berbasis GUI (Graphical User Interface) merupakan salah satu cara untuk mempermudah proses pencatatan serta penyimpanan data. Selain secara teknis efektif dan efisien dalam proses pelaksanaannya, data-data tersebut dapat diolah lagi menjadi informasi yang lebih berarti.

Fokus dari penelitian ini adalah mengembangkan sebuah aplikasi perangkat lunak yang nantinya akan digunakan oleh petugas sekretariat Gereja Katolik Paroki Santo Petrus Palembang didalam mengelola administrasi Gereja. Metode pengembangan perangkat lunak yang digunakan adalah metode extreme programming (XP) dikarenakan penggunaan $X P$ pada suatu proyek dapat menghasilkan kualitas tinggi dengan desain sederhana [7]. Metode XP sendiri merupakan sebuah metode pengembangan sistem informasi yang tangkas 
(agile), serta banyak digunakan untuk proyek skala kecil yang mengakomodasi pengembangan aplikasi dengan cepat [3].

\section{LITERATUR}

Agile Software Development merupakan sebuah konsep metode pengembangan sistem yang mengandung arti cepat dilakukan, cepat merespon perubahan yang diminta oleh klien atau pengguna, dan melibatkan klien secara aktif dalam proses sehingga perangkat lunak atau modul yang dihasilkan merupakan kolaborasi dari setiap pihak yang terlibat [1]. Metode pengembangan perangkat lunak agile menyediakan paradigma pembangunan secara berulang dan evolusi dengan lebih menekankan pada perubahan persyaratan, kepuasan pelanggan, dan kolaborasi tim daripada kepentingan proses dan alat [3]. Metode agile telah dikembangkan untuk merancang perangkat lunak tanpa mendesain ulang (redesigning), membangun kembali (rebuilding), dan merubah struktur kode pemograman (refactoring). Oleh karena itu, 90\% industri TI menerapkan metode agile untuk mengembangkan perangkat lunak [6].

Beberapa tipe metode pengembangan sistem yang mengadopsi konsep metode Agile Software Development diantaranya Adaptive Software Development (ASD), Agile Unified Process (AUP), Crystal Methods, Dynamic Systems Development Methodology (DSDM), eXtreme Programming (XP), Feature Driven Development (FDD), Kanban, Lean Software Development (LSD), Scrum, Scrumban. Agile method didasarkan pada teknik peningkatan iteratif. Sebagai metode yang berbasis iterasi, setiap iterasi mewakili proses pada metode Software Development Life Cycle (SDLC) skala kecil dan mandiri [2].

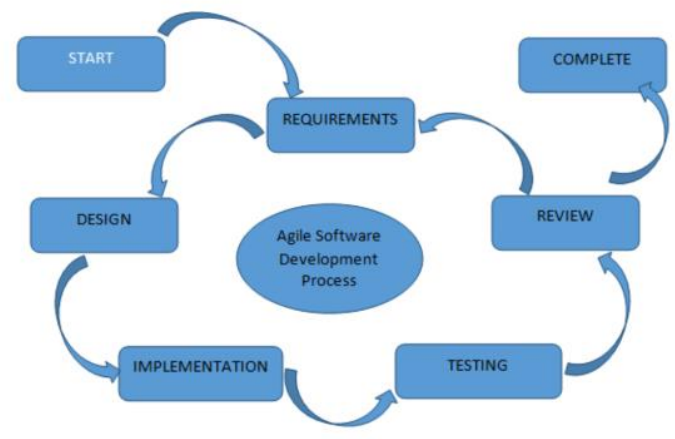

Gambar 1. Metode Extreme Programming

Metode XP dicetuskan oleh Kent Beck dan terus berkembang sebagai jawaban atas masalah-masalah yang ditimbulkan pada lamanya pengembangan perangkat lunak dengan metode pengembangan tradisional dikarenakan memiliki kecendrungan membutuhkan waktu yang lama untuk tiap tahapannya mulai dari perancanaan, analisa sampai dengan perancangan sistem.

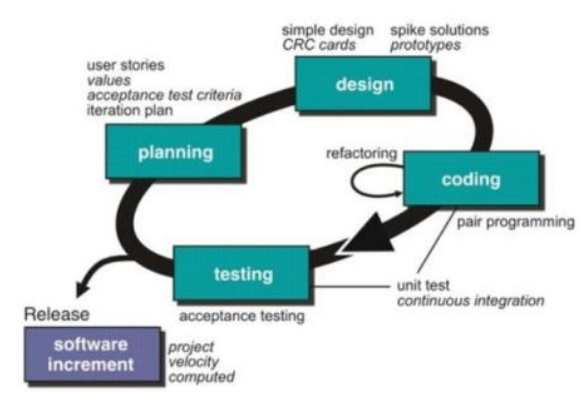

Gambar 2. Metode Extreme Programming

Didalam tahapannya, XP menawarkan proses yang lebih singkat sesuai dengan fokus pada apa yang ingin dicapai. Kent Beck mengungkapkan bahwa terdapat beberapa nilai dasar dari metode XP [4] yaitu :

1) Communication berarti memfokuskan komunikasi yang baik antara programmer

2) dengan user maupun antar programmer.

3) Courage yang berarti pengembang perangkat lunak harus selalu memiliki keyakinan, keberanian dan integritas dalam melakukan tugasnya.

4) Simplicity berarti melakukan semua dengan sederhana.

5) Feedback berarti mengandalkan feedback sehingga dibutuhkan anggota tim yang

6) berkualitas.

7) Quality Work berarti bahwa proses yang berkualitas berimplikasi pada perangkat lunak yang berkualitas sebagai hasil akhirnya.

Terdapat 4 tahapan dalam pengembangan perangkat lunak dengan menggunakan XP [10], yaitu :

1) Planning (Perencanaan).

Merupakan tahap awal dimana pengembang membuat perencanaan untuk menggambarkan hasil keluaran dan fungsional dari aplikasi. Kegiatan perencanaan meliputi identifikasi permasalahan, menganalisa kebutuhan sampai dengan penetapan jadwal pelaksanaan pembangunan. Informasi mengenai kebutuhan-kebutuhan tersebut didapat dari dokumentasi user story.

2) Design (Desain).

Tahap desain merupakan bagian dari perancangan aplikasi yang sesuai dengan kebutuhan dari penggunaannya yaitu yang berdasarkan pada fase planning. Pada fase ini dilakukan kegiatan pemodelan sistem (Use Case Diagram, Class Diagram, Activity Diagram) dan pemodelan arsitektur dengan menggunakan UML (Unifed Model Diagram) kemudian dilanjutkan dengan pemodelan basis data yang menggunakan ERD (Entity Relationship Diagram).

3) Coding (Pengkodean).

Pada fase ini dilakukan proses pembuatan kode program pada software yang digunakan dalam pengembangan aplikasi. Selain itu itu dilakukan juga pengujian kode program yang bertujuan untuk mengurangi waktu pengembangan dan meminimalisir adanya bugs atau errors pada aplikasi dengan menggunakan teknik Test Driven Development (TDD) [9]. 
4) Testing (Pengujian).

Tahapan ini merupakan fase terakhir untuk menguji apakah aplikasi yang dibangun sesuai dengan fitur dan fungsionalitas yang diharapkan oleh pengguna. Untuk melakukan pengujian terhadap aplikasi digunakan dua buah metode yaitu pengujian unit test dan pengujian acceptance. Pengujian unit test menggunakan teknik white box yang bertujuan untuk mengetahui kesesuaian alur kode program dengan harapan pengguna. Sementara pengujian acceptance menggunakan teknik black box yang bertujuan untuk mengetahui penerimaan pengguna terhadap aplikasi yang dibangun.

\section{METODE PENELITIAN}

Untuk memperoleh data yang tepat dan dapat diolah sesuai dengan tujuan, penulis menggunakan beberapa teknik didalam pengumpulan data. Teknik yang digunakan yaitu :

A. Pengamatan

Teknik pengumpulan data yang dilakukan dengan cara mengamati objek yang diteliti untuk memahami proses pengolahan data yang sedang berjalan, melihat kendala yang dialami, menganalisa kebutuhan perangkat yang diperlukan dalam membangun aplikasi.

B. Wawancara

Teknik wawancara dilakukan dengan cara mengajukan pertanyaan kepada Pastor dan petugas Sekretariat Gereja Paroki mengenai sistem yang berjalan, proses penyimpanan data, luaran yang diperlukan baik bagi jemaat dan kebutuhan administrasi Gereja, media penyimpanan yang digunakan saat ini, dan mendengarkan saran didalam pengembangan aplikasi. C. Kepustakaan

Penulis melakukan pengumpulan data untuk memperoleh informasi mengenai metode extreme programming dan administrasi sekretariat gereja melalui studi pustaka yang bersumber dari buku dan jurnal elektronik baik yang itu yang berskala nasional maupun internasional.

Pada penelitian ini dilakukan beberapa proses kegiatan yang mengadopsi tahapan yang terdapat pada metode Extreme

Programming (XP).

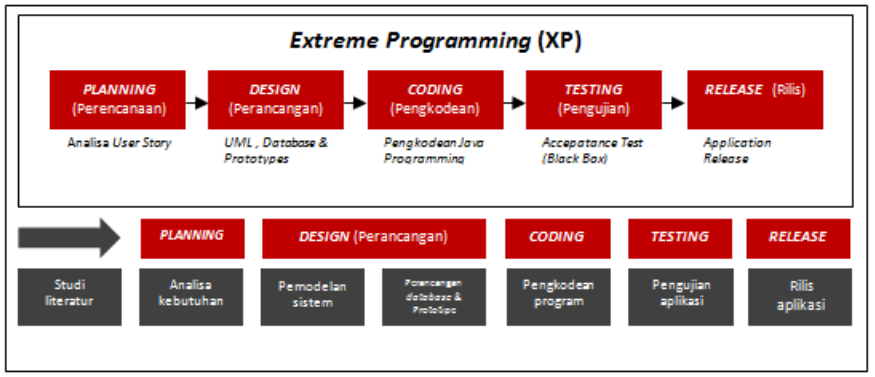

Gambar 3. Adopsi XP dalam Metode Penelitian

Tahap pertama : fase planning (perencanaan)

Dimulai dari fase perencanaan dimana dilakukan analisa kebutuhan yang didapat dari pengguna melalui user story. Penggalian informasi tentang kebutuhan aplikasi dilakukan melalui proses wawancara dengan petugas sekretariat paroki untuk mengetahui lingkup pekerjaan dan keperluan output data. Selain itu juga penggalian informasi didapat dari pengamatan dokumen cetak yang selama ini telah berjalan secara manual di sekretariat paroki. Setelah mendapatkan informasi kebutuhan yang diinginkan dari pengguna maka dilanjutkan ke tahap analisa kebutuhan fungsional dan non fungsional. Proses iterasi akan terus dilakukan apabila pengguna meminta penambahan kebutuhan sampai dengan semua kebutuhan terpenuhi.

\section{Tahap kedua : fase design (perancangan)}

Pada fase perancangan dilakukan kegiatan pemodelan sistem yang digunakan untuk melihat aktor yang terlibat didalam penggunaan aplikasi (use case diagram), mendefinisikan struktur sistem di dalam mendefinisikan kelas (class diagram) dan menentukan workflows aplikasi yang akan dirancang (activity diagram) dengan menggunakan bahasa pemodelan UML (Unified Model Diagram). Selain membuat pemodelan sistem, pada fase ini juga dilakukan perancangan database dan pembuatan prototipe yang digunakan untuk menunjukkan gambaran kepada pengguna mengenai antarmuka aplikasi. Proses perancangan ini dapat dilakukan secara berulang kali apabila terdapat perubahan yang dibutuhkan oleh pengguna.

\section{Tahap ketiga : fase coding (pengkodean)}

Pada fase coding dilakukan kegiatan penulisan kode program dengan menggunakan software bahasa pemograman Java yang mengacu pada hasil pemodelan sistem dan pembuatan prototipe pada fase perancangan.

\section{Tahap keempat : fase test (pengujian)}

Pada fase test dilakukan pengujian terhadap aplikasi dengan menggunakan metode black box testing. Pengujian black box berguna untuk melihat kesesuaian elemen-elemen aplikasi terhadap fungsionalitasnya secara keseluruhan tanpa perlu mengetahui apa yang terjadi di dalam aplikasi tetapi fokus pada proses masukan (input) dan keluaran (output) yang dilakukan oleh pengguna aplikasi. Tahap pengujian sangat berguna untuk menguji apakah aplikasi yang dibuat sudah sesuai dengan kebutuhan dan memastikan aplikasi yang dibuat tidak terdapat kesalahan.

Tahap kelima : fase release (rilis aplikasi)

Fase ini merupakan fase terakhir dimana pada fase release dilakukan rilis aplikasi yang akan diimplementasikan di Gereja Katolik Paroki Santo Petrus Palembang. Aplikasi perangkat lunak tersebut akan di install ke perangkat komputer sekretariat Paroki dan digunakan oleh petugas sekretariat serta Pastor Paroki.

\section{HASIL DAN PEMBAHASAN}

\section{A. Fase Planning (Perencanaan)}

Berikut beberapa permasalahan yang teridentifikasi melalui hasil wawancara dan observasi.

1) Pengolahan data yang dilakukan masih terpisah. Hanya ada satu aplikasi yang khususdigunakan untuk penyimpanan data Sakramen Baptis. Sementara penyimpanan data yang 
lainnya seperti data umat dan Sakramen Krisma masih diolah secara terpisah menggunakan aplikasi Microsoft Excel.

2) Tidak adanya pencatatan atau pendokumentasian yang baik terhadap data kematian umat, perpindahan umat antar paroki, maupun data kartu keluarga umat.

3) Pencetakan sertifikat Sakramen Baptis dan Sakramen

Krisma yang nantinya akan diberikan kepada orang tua Baptis maupun peserta Sakramen Krisma masih dilakukan secara manual.

Seteleh mengidentifikasi permasalahan maka dapat didefinisikan kebutuhan fungsional dan non fungsional dari aplikasi yang akan dibangun.

Kebutuhan Fungsional

1) Aplikasi dapat digunakan untuk menyimpan data profil paroki, data pastor, master data umat, data Sakramen Baptis, data Sakramen Krisma, data Kartu Keluarga dan data kematian umat.

2) Aplikasi mampu untuk mengolah data perpindahan umat baik itu yang datang maupun pindah, sehingga informasi mengenai data jumlah umat paroki selalu valid dan up to date.

3) Aplikasi menyediakan fitur yang dapat digunakan untuk mencetak sertifikat sakramen Baptis dan sakramen Krisma pada aplikasi.

Kebutuhan Non Fungsional

1) Aplikasi hanya bisa diakses atau digunakan oleh petugas admin sekretariat Paroki.

2) Aplikasi harus terpasang atau terinstall pada perangkat komputer sekretariat Paroki.

3) Aplikasi memiliki antar tampilan antar muka yang user friendly sehingga mudah untuk dipahami.

\section{B. Fase Design (Perancangan)}

Pada tahap ini dilakukan kegiatan pemodelan sistem, pemodelan arstitektur, desain basis data dan desain prototipe yang berguna sebagai gambaran antar muka bagi pengguna aplikasi.

\section{Pemodelan Sistem}

- Use Case Diagram

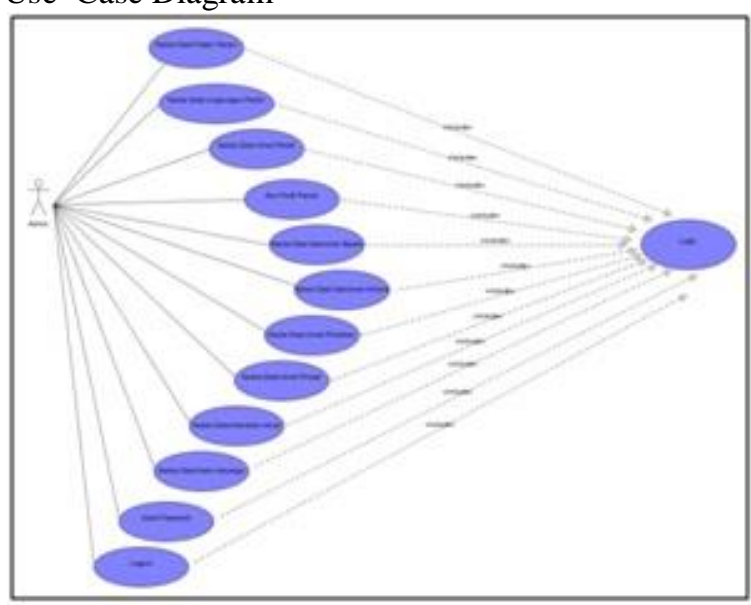

Gambar 4. Use Case Diagram Aplikasi Sekretariat Paroki
- Class Diagram

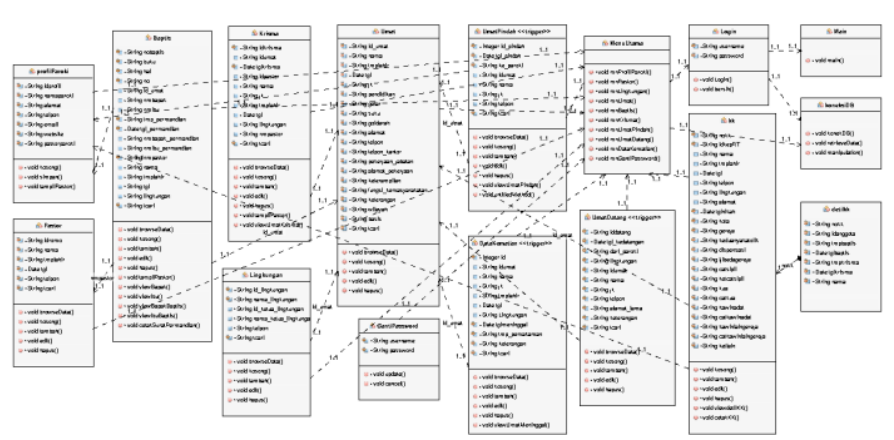

Gambar 5. Class Diagram Aplikasi Sekretariat Paroki

\section{- Activity Diagram}

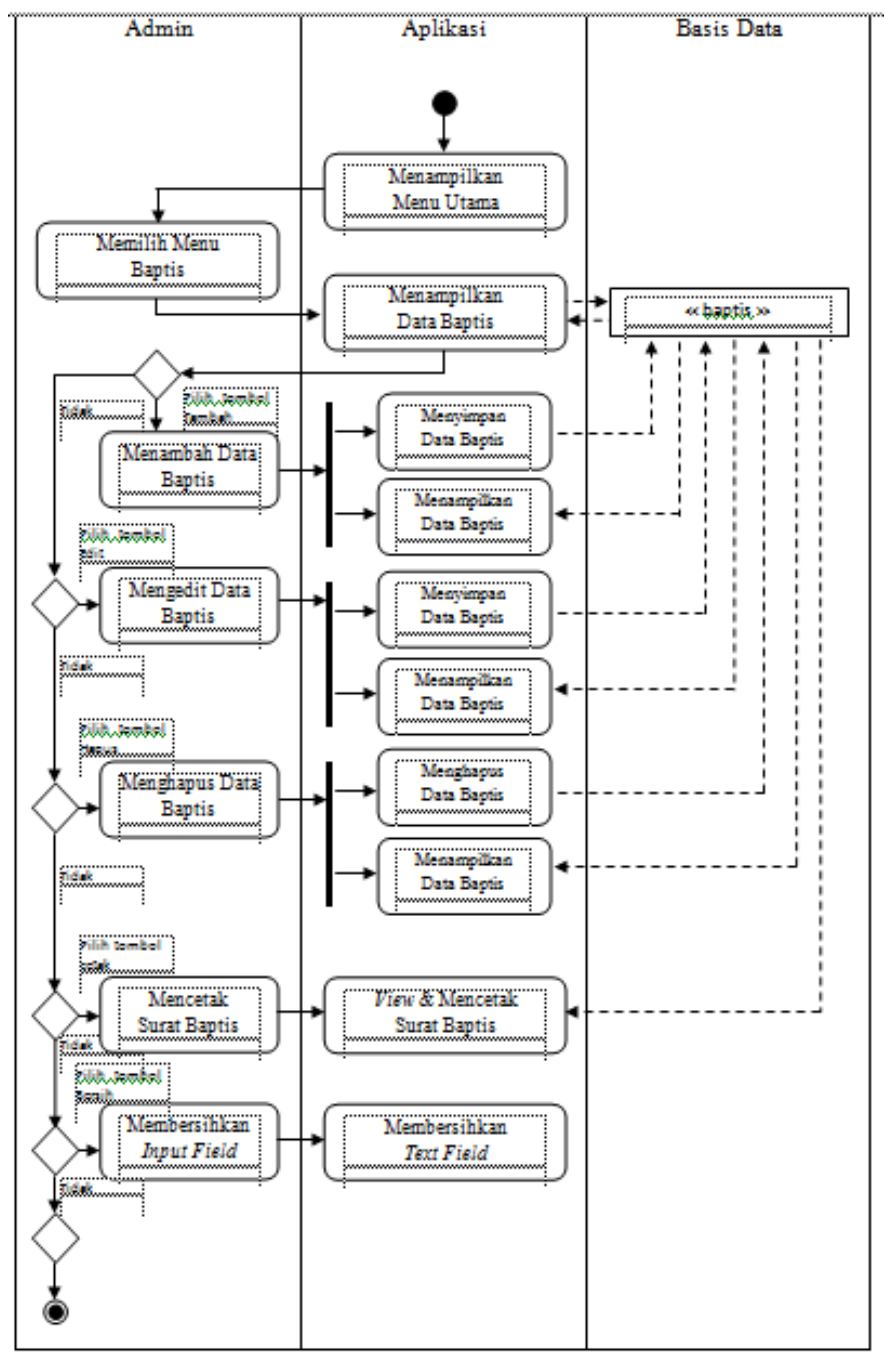

Gambar 6. Activity Kelola Data Sakramen Baptis 


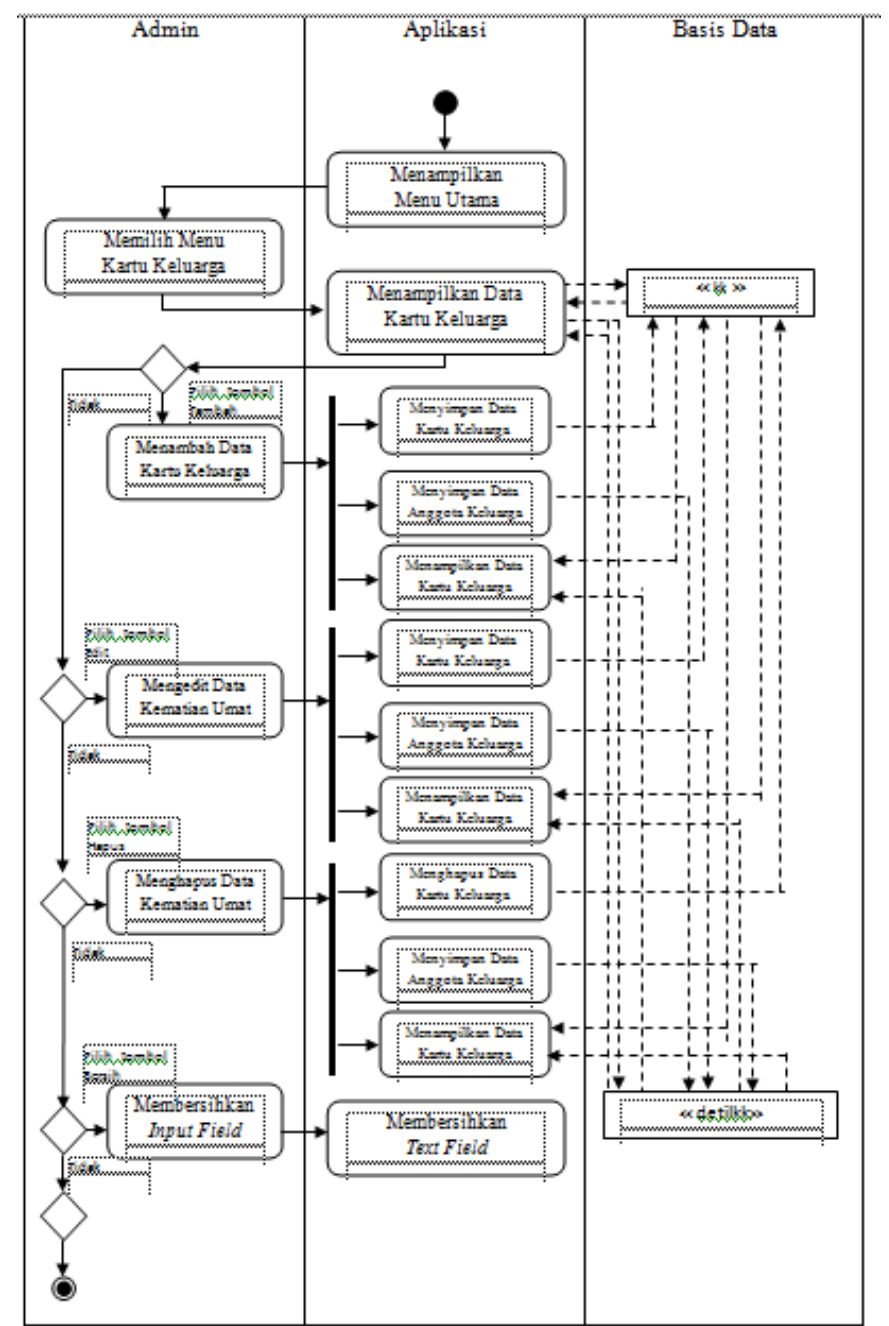

Gambar 7. Activity Kelola Kartu keluarga

2. Pemodelan Arsitektur

- Component Diagram

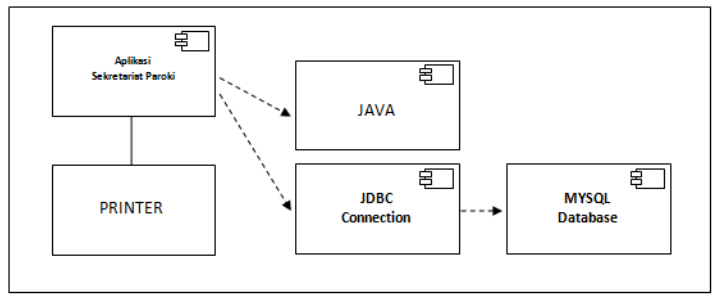

Gambar 8. Component Diagram

- Deployment Diagram

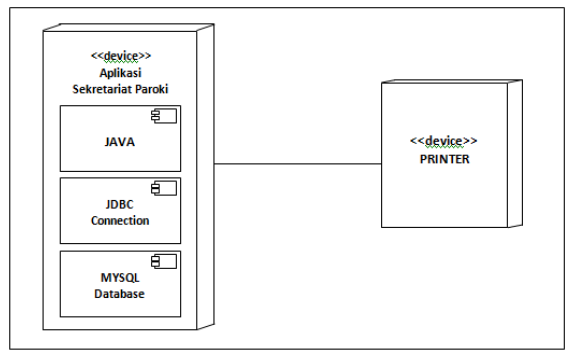

Gambar 9. Deployment Diagram
3. Desain Basis Data

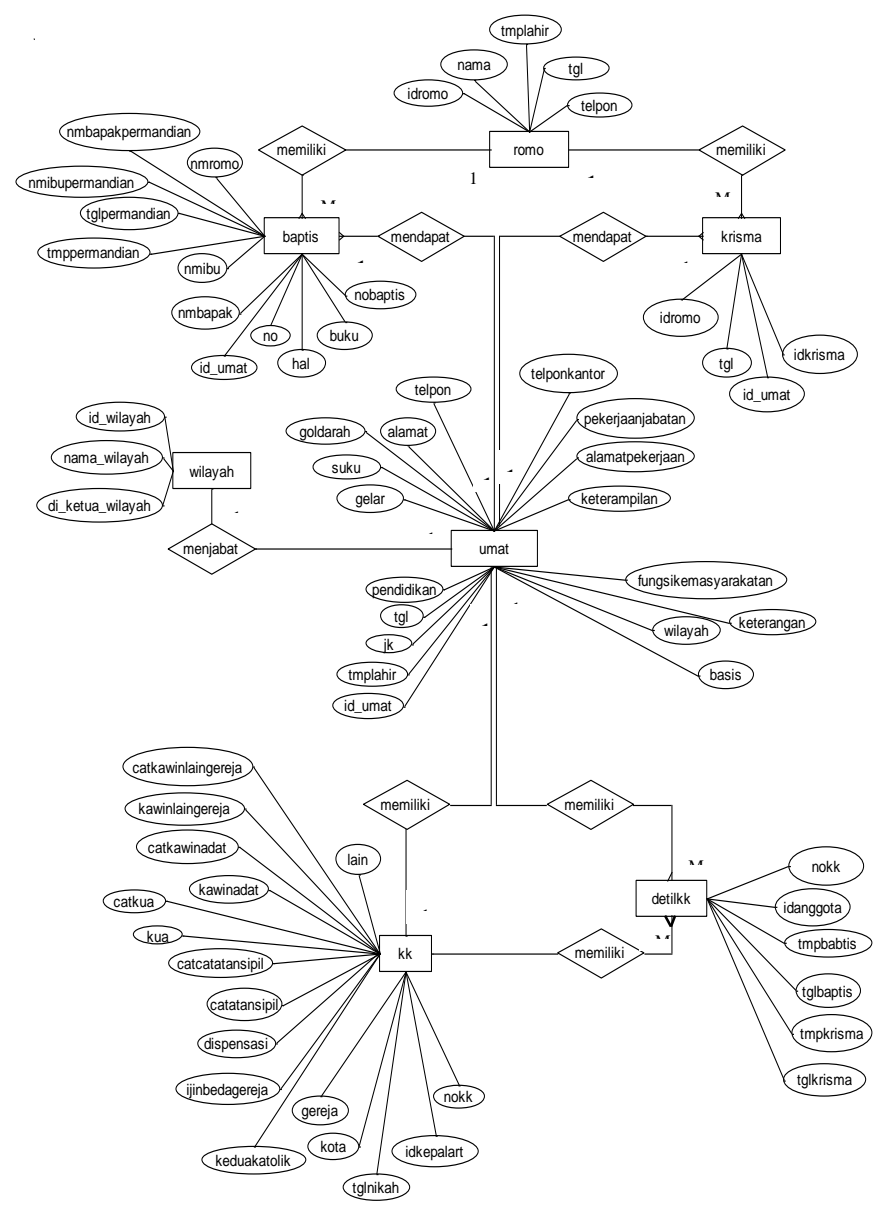

Gambar 10. Entity Relationship Diagram

\section{Desain Prototipe (User Interface)}

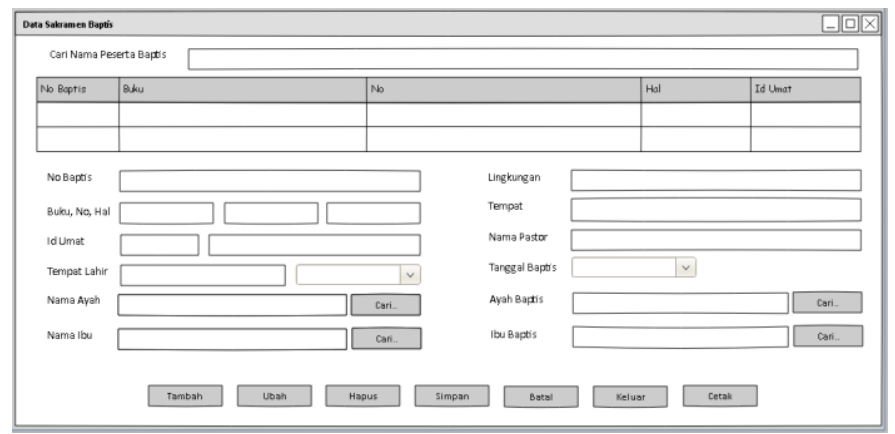

Gambar 11. Desain Prototipe Form Data Sakramen Baptis

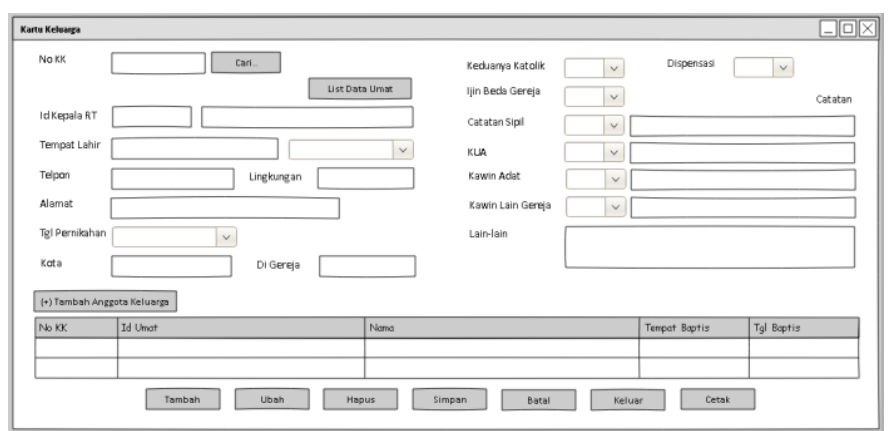

Gambar 12. Desain Prototipe Form Data Kartu Keluarga 
C. Fase Coding (Pengkodean)

Pada tahap pengkodean dilakukan kegiatan penulisan kode program dengan menggunakan bahasa pemrograman java dan basis data mysql sebagai media penyimpanan datanya. Sementara IDE Netbeans digunakan untuk mempermudah di dalam penulisan coding, mengkompilasi maupun mencari kesalahan program.

D. Fase Testing (Pengujian)

TABEL 1.

PENGUJIAN FUNGSI PENGELOLAAN DATA SAKRAMEN BAPTIS

\begin{tabular}{|c|c|c|c|}
\hline Skenario & $\begin{array}{l}\text { Yang } \\
\text { Diharapkan }\end{array}$ & $\begin{array}{c}\text { Hasil } \\
\text { Pengujian }\end{array}$ & Kesimpulan \\
\hline $\begin{array}{l}\text { Menekan } \\
\text { tombol } \\
\text { Tambah. }\end{array}$ & $\begin{array}{l}\text { Dapat } \\
\text { mengosongkan } \\
\text { text box untuk } \\
\text { menambah data } \\
\text { Baptis. }\end{array}$ & Sesuai harapan & Valid \\
\hline $\begin{array}{l}\text { Menekan } \\
\text { tombol } \\
\text { Simpan. }\end{array}$ & $\begin{array}{l}\text { Dapat } \\
\text { meyimpan data } \\
\text { Baptis. }\end{array}$ & Sesuai harapan & Valid \\
\hline $\begin{array}{l}\text { Menekan } \\
\text { tombol } \\
\text { Ubah lalu } \\
\text { tombol } \\
\text { Update.. }\end{array}$ & $\begin{array}{l}\text { Dapat } \\
\text { mengubah / } \\
\text { update data } \\
\text { Baptis. }\end{array}$ & Sesuai harapan & Valid \\
\hline $\begin{array}{l}\text { Menekan } \\
\text { tombol } \\
\text { Hapus. }\end{array}$ & $\begin{array}{l}\text { Dapat } \\
\text { menghapus data } \\
\text { Baptis. }\end{array}$ & Sesuai harapan & Valid \\
\hline $\begin{array}{l}\text { Menekan } \\
\text { tombol } \\
\text { Batal }\end{array}$ & $\begin{array}{l}\text { Dapat } \\
\text { mengosongkan } \\
\text { text box yang } \\
\text { sudah ditulis. }\end{array}$ & Sesuai harapan & Valid \\
\hline $\begin{array}{l}\text { Menekan } \\
\text { tombol } \\
\text { Keluar }\end{array}$ & $\begin{array}{l}\text { Dapat keluar } \\
\text { dari form Data } \\
\text { Baptis. }\end{array}$ & Sesuai harapan & Valid \\
\hline $\begin{array}{l}\text { Jika text } \\
\text { input No } \\
\text { Baptis } \\
\text { kosong. }\end{array}$ & $\begin{array}{l}\text { Menampilkan } \\
\text { pesan untuk } \\
\text { mengisi data No } \\
\text { Baptis terlebih } \\
\text { dahulu. }\end{array}$ & Sesuai harapan & Valid \\
\hline $\begin{array}{l}\text { Jika data } \\
\text { No Baptis } \\
\text { yang dientri } \\
\text { kembar. }\end{array}$ & $\begin{array}{l}\text { Menampilkan } \\
\text { pesan } \\
\text { peringatan } \\
\text { bahwa No } \\
\text { Baptis telah }\end{array}$ & Sesuai harapan & Valid \\
\hline
\end{tabular}

\begin{tabular}{llll}
\hline & terdaftar. & & \\
\hline Menekan & Menampilkan & Sesuai harapan & Valid \\
tombol & preview cetak & & \\
cetak. & sertifikat & & \\
& Sakramen & \\
& Baptis. & \\
\hline
\end{tabular}

TABEL 2.

PENGUJIAN FUNGSI PENGELOLAAN DATA KARTU KELUARGA.

\begin{tabular}{|c|c|c|c|}
\hline Skenario & $\begin{array}{l}\text { Yang } \\
\text { Diharapkan }\end{array}$ & $\begin{array}{c}\text { Hasil } \\
\text { Pengujian }\end{array}$ & Kesimpulan \\
\hline $\begin{array}{l}\text { Menekan } \\
\text { tombol } \\
\text { Tambah. }\end{array}$ & $\begin{array}{l}\text { Dapat } \\
\text { mengosongkan } \\
\text { text box untuk } \\
\text { menambah data } \\
\text { kartu keluarga. }\end{array}$ & Sesuai harapan & Valid \\
\hline $\begin{array}{l}\text { Menekan } \\
\text { tombol } \\
\text { Cari. }\end{array}$ & $\begin{array}{l}\text { Menampilkan } \\
\text { list daftar nama } \\
\text { kepala keluarga. }\end{array}$ & Sesuai harapan & Valid \\
\hline $\begin{array}{l}\text { Menekan } \\
\text { tombol } \\
\text { Anggota } \\
\text { Keluarga. }\end{array}$ & $\begin{array}{l}\text { Dapat } \\
\text { menambahkan } \\
\text { data anggota } \\
\text { keluarga. }\end{array}$ & Sesuai harapan & Valid \\
\hline $\begin{array}{l}\text { Menekan } \\
\text { tombol } \\
\text { Simpan. }\end{array}$ & $\begin{array}{l}\text { Dapat } \\
\text { meyimpan data } \\
\text { kartu keluarga. }\end{array}$ & Sesuai harapan & Valid \\
\hline $\begin{array}{l}\text { Menekan } \\
\text { tombol } \\
\text { Ubah lalu } \\
\text { tombol } \\
\text { Update.. }\end{array}$ & $\begin{array}{l}\text { Dapat } \\
\text { mengubah / } \\
\text { update data } \\
\text { kartu keluarga. }\end{array}$ & Sesuai harapan & Valid \\
\hline $\begin{array}{l}\text { Menekan } \\
\text { tombol } \\
\text { Hapus. }\end{array}$ & $\begin{array}{l}\text { Dapat } \\
\text { menghapus data } \\
\text { kartu keluarga. }\end{array}$ & Sesuai harapan & Valid \\
\hline $\begin{array}{l}\text { Menekan } \\
\text { tombol } \\
\text { Batal }\end{array}$ & $\begin{array}{l}\text { Dapat } \\
\text { mengosongkan } \\
\text { text box yang } \\
\text { sudah ditulis. }\end{array}$ & Sesuai harapan & Valid \\
\hline $\begin{array}{l}\text { Menekan } \\
\text { tombol } \\
\text { Keluar }\end{array}$ & $\begin{array}{l}\text { Dapat keluar } \\
\text { dari form Kartu } \\
\text { Keluarga. }\end{array}$ & Sesuai harapan & Valid \\
\hline $\begin{array}{l}\text { Jika text } \\
\text { input No } \\
\text { Kartu }\end{array}$ & $\begin{array}{l}\text { Menampilkan } \\
\text { pesan untuk } \\
\text { mengisi data No }\end{array}$ & Sesuai harapan & Valid \\
\hline
\end{tabular}




\begin{tabular}{llll}
\hline $\begin{array}{l}\text { Keluarga } \\
\text { kosong. }\end{array}$ & $\begin{array}{l}\text { Kartu Keluarga } \\
\text { terlebih dahulu. }\end{array}$ & \\
\hline Jika data & Menampilkan & Sesuai harapan & Valid \\
No Kartu & pesan & \\
Keluarga & peringatan & & \\
yang dientri & bahwa No Kartu & & \\
kembar. & Keluarga telah & & \\
& terdaftar. & & \\
\hline Menekan & Menampilkan & Sesuai harapan & Valid \\
tombol & preview cetak & \\
cetak. & Kartu Keluarga. & \\
\hline
\end{tabular}

\section{KESIMPULAN DAN SARAN}

Kesimpulan yang didapat dari penelitian ini adalah sebagai berikut:

1) Penggunaan metode extreme programming (XP) dipandang cocok dan efektif didalam membangun perangkat lunak sederhana seperti Aplikasi Sekretariat Paroki. Hal ini terbukti dari hasil pengujian Black Box yang menunjukkan bahwa hasil penggunaan aplikasi sesuai dengan yang diharapkan oleh pengguna (user).

2) Aplikasi Sekretariat Paroki memberikan kemudahan bagi petugas sekretariat didalam kegiatan administrasi seperti pencatatan dan pengelolaan data yang berkaitan dengan umat Paroki Gereja Santo Petrus Palembang.

Saran yang dapat dilakukan untuk pengembangan kedepan adalah :

1) Karena aplikasi hanya digunakan oleh petugas sekretariat Paroki maka menyebabkan seluruh proses pencatatan dan pengolahan data umat berfokus pada satu orang saja, oleh karena itu kedepan perlu dipertimbangkan untuk dilakukan pengembangan aplikasi berbasis web agar aplikasi dapat diakses oleh Kepala Lingkungan sehingga dapat membantu petugas sekretariat terkhusus yang berkaitan dengan entri data umat pindahan (datang) dan umat pindah Paroki.

2) Disarankan untuk memberikan penambahan fitur pengelolaan data komuni pertama, Sakramen Perkawinan, informasi umat lansia yang sakit, dan data umat miskin.

\section{REFERENSI}

[1] Abrahamsson,Pekka, et. al. "Agile Software Development MethodsReview and Analysis". s.1.:VTT Publications 478, 2002.

[2] Al-Zewairi, M. , Biltawi,M., Etaiwi, W., Shaout, A.."Agile Software Development Methodologies: Survey of Surveys". International Journal of Computer Science and Telecommunications Volume 5, March 2017.

[3] Anwer, F., Aftab, S., Shah,S.S.M., Waheed, U.. "Comparative Analysis of Two Popular Agile Process Models: Extreme Programming and
Scrum". International Journal of Computer Science and Telecommunications Volume 8, Issue 2, March 2017.

[4] Fatoni, A., Dwi, D.. "Rancang Bangun Sistem Extreme Programming Sebagai Metodologi Pengembangan Sistem”. Jurnal PROSISKO Vol. 3 No. 1 Maret 2016.

[5] Kementrian Pendidikan dan Kebudayaan. https://kbbi.kemdikbud.go.id/entri/gereja (diakses 24 Mei 2019).

[6] Kotaiah, B., Khalil, M.A.. "Approaches for development of Software Projects: Agile methodology". International Journal of Advanced Research in Computer Science Volume 8, No.1 , February 2017.

[7] Krishna, T.S., Kanth, C. P., Krishna, C. V., \& Krishna, T. V.“Survey on Extreme Programming in Software Engineering". International Journal of Computer Trends and Technology, 2(2), 21-24, 2015.

[8] Laurens, J.M.. "Kajian Sosiolinguistik Penggantian Nama pada Masyarakat Rembang”.Disertasi. Program Doktor Arsitektur Sekolah Pascasarjana Universitas Katolik Parahyangan Bandung, 2017.

[9] Prasetya, A., Brata, A.H., Ananta, M.T.. "Pengembangan Aplikasi Pemesanan Lapangan Futsal Di Kota Malang Berbasis Android Menggunakan Metode Pengembangan Extreme Programming (Studi Kasus Champion Tidar, Zona SM Futsal, dan Viva Futsal). Jurnal Pengembangan Teknologi Informasi dan Ilmu Komputer Vol. 2, No. 12, Desember 2018, hlm. 7293-7301, 2018.

[10] Pressman, R.S.. Software Engineering: A Practitioner's Approach. Singapore : The McGraw-Hill Companies, 2010.

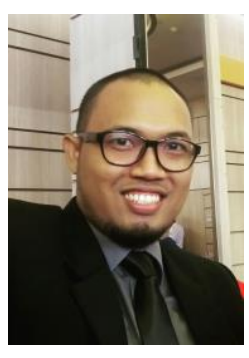

Stefanus Setyo Wibagso, S.Kom., M.Kom. lahir di Kota Palembang pada tanggal 14 bulan November tahun 1981. Penulis mendapatkan gelar Sarjana Komputer (S.Kom) pada tahun 2006 dari STMIK Palcomtech Palembang Jurusan Sistem Informasi Bisnis, kemudian melanjutkan pendidikan S2 di

Program Pasca Sarjana MTI Universitas Bina Darma Jurusan Software Engineering, Palembang, Indonesia, serta menyelesaikan pendidikan Master pada tahun 2012. Saat ini bekerja sebagai dosen pada Universitas Katolik Musi Charitas Palembang Fakultas Sains \& Teknologi pada Program Studi Sistem Informasi. Adapun bidang ilmu yang ditekuni saat ini adalah Web Programming, Java, Joomla Content Management System dan Enterprise Information System, . 